\title{
Who Are Your Friends in Class?
}

\section{The Effects of Classroom Composition on Students' Reciprocal Friendship Nominations}

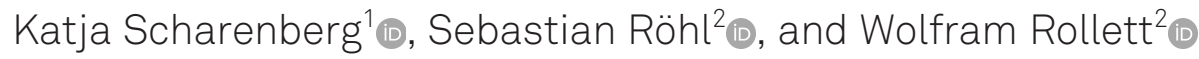 \\ ${ }^{1}$ Institut für Soziologie, Pädagogische Hochschule Freiburg, Germany \\ ${ }^{2}$ Institut für Erziehungswissenschaft, Pädagogische Hochschule Freiburg, Germany
}

\begin{abstract}
Educational settings such as classrooms provide important opportunities for social learning through interactions with peers. Our paper addresses the research question of whether and to what extent classroom composition characteristics make a difference. We carried out multilevel analyses based on a sample of $n=791$ students in 48 classrooms (grades $5-7$ ) in inclusive lower-secondary comprehensive schools in Baden-Württemberg (Germany). $22.6 \%$ of the variance in students' reciprocal friendship nominations were attributable to classroom-level differences. A higher average socioeconomic status and, respectively, a lower percentage of immigrant students negatively affected the number of reciprocal friendship nominations within classrooms. These results indicate that more privileged classroom settings can be related to less dense friendship networks of students. Our findings can be understood as an impulse to consider contextual factors when evaluating and addressing the social structure of classrooms in research and practice.
\end{abstract}

Keywords: friendships, peer relations, classroom, classroom composition, secondary school

\begin{abstract}
Wer sind deine Freunde in der Klasse? Effekte der Klassenkomposition auf reziproke Freundschaftsnominierungen
Zusammenfassung: Bildungskontexte wie zum Beispiel Schulklassen bieten wichtige Gelegenheiten zum sozialen Lernen und zur sozialen Interaktion mit Gleichaltrigen. Unser Beitrag geht der Frage nach, ob und inwieweit es dabei auch auf die Klassenkomposition ankommt. Die dazu durchgeführten Mehrebenenanalysen basieren auf einer Stichprobe von $n=791$ Schüler/inne/n aus 48 Schulklassen (Jahrgangsstufe $5-7)$ in inklusiven Gemeinschaftsschulen in Baden-Württemberg. 22.6\% der Varianz der reziproken Freundschaftsnominierungen der Schüler/innen entfielen auf Unterschiede zwischen Schulklassen. Ein höherer mittlerer sozioökonomischer Status bzw. ein niedrigerer Migrantenanteil erwiesen sich als nachteilig für die Anzahl reziproker Freundschaftsnominierungen in den Schulklassen. Diese Ergebnisse weisen darauf hin, dass privilegiertere Klassenkontexte mit weniger dichten Freundschaftsnetzwerken der Schüler/innen einhergehen können. Unsere Befunde können somit als Impuls verstanden werden, in Forschung und Praxis Kontextfaktoren in den Blick zu nehmen, wenn die soziale Struktur von Schulklassen evaluiert bzw. adressiert werden soll.
\end{abstract}

Schlüsselwörter: Freundschaften, Peerbeziehungen, Schulklasse, Klassenkomposition, Sekundarstufe

Social relations with peers are important for students' development. Relationships with schoolmates/classmates can influence students' sense of belonging, their schoolrelated well-being, and their academic motivation (e.g., Gillen-O’Neel \& Fuligni, 2013; Pittman \& Richmond, 2007). Thus, classrooms provide opportunity structures for establishing friendships. But classrooms can systematically differ in how closely classmates come into contact with each other (Kulawiak \& Wilbert, 2015; Schwab, 2016). In our judgement, the composition of a class and how it affects the occurrence of friendships between classmates has not yet been empirically investigated. The present study therefore examines the contextual effects of classroom composition on students' friendships. We combine approaches of research into school effectiveness and peer interaction using a multilevel design.

\section{The Importance of Peer Relations for Students' Development}

In childhood and adolescence, educational settings such as schools and classrooms are important places to make friends: More than half of friendships of school-age students begin in classroom or school settings (McCormick et al., 2015). The kind of social relations students maintain with their peers at school is important for their cognitive, motivational, emotional, and social development (e.g., Deci \& Ryan, 2008; Gillen-O'Neel \& Fuligni, 2013; Pittman \& Richmond, 2007).

The sense of having positive relationships with others and experiencing social belonging and social relatedness is considered a fundamental human need (Baumeister \& 
Leary, 1995). The satisfaction of this need is directly linked to emotional and motivational processes and can thus influence motivation, behavior, affect, and wellbeing (Deci \& Ryan, 1985). At the same time, social interactions with peers are known to influence individual attitudes and behavior, for example, by establishing group norms (Duffy \& Nesdale, 2009; Festinger et al., 1950; Jones et al., 2012).

\section{Peer Relations and Their Correlates}

The effects of experiencing positive or negative social relationships on learning outcomes such as academic achievement have been confirmed by many studies. Typically, students with higher acceptance by their peers benefit more from participating in class, e.g., by doing better at school (Cillessen \& van den Berg, 2012). Several studies proved the expectation that feelings of relatedness to peers in school are closely linked to students' academic achievement as well as to outcomes like academic motivation, intrinsic and utility values, or achievement goal orientations (e.g., Gillen-O'Neel \& Fuligni, 2013; Looser, 2009; Vanwynsberghe et al., 2017). Intervention studies promoting students' sense of social belonging in school were found to increase, for example, academic achievement and positive self-beliefs of minority group students (e.g., Hannover et al., 2020; Walton \& Cohen, 2011). Contrarily, feelings of aloneness or social exclusion were found to be related to a decrease in cognitive performance and graduation test scores (Baumeister et al., 2002). Furthermore, the perception of social isolation and loneliness can also have detrimental effects on noncognitive outcomes such as subjective well-being and happiness (Lyubomirsky et al., 2005).

At the same time, peers' attitudes toward learning, motivation, and behavior in class can influence students' own individual attitudes toward school and learning behavior (Zander \& Kreutzmann, 2018). Accordingly, peers were found to influence the problematic school behavior of other classmates, like not doing homework or not paying attention in class (Geven et al., 2013). Furthermore, Müller et al. (2017) showed that aggregated self-reported delinquency among classmates predicts the development of individual delinquent behavior in early adolescence.

Concerning the social development of students, social experiences in childhood and early school age influence later social behavior. On the one hand, a higher quality of friendships in childhood may lower the risk of demonstrating aggressive behavior at later ages; on the other hand, rejection by the peer group at school is related to later antisocial behavior and manifest conduct problems (Hay et al., 2004). Similarly, victimization by peers at earlier school age might lead to problematic internalizing or externalizing behaviors and social problems (Hanish \& Guerra, 2002). Moreover, being rejected by non-aggressive peers can lead to the establishment of friendships with more aggressive peers in early adolescence (Dishion et al., 1991). Such groups of aggressive peers can establish social norms which reinforce adolescents' deviance and may stimulate delinquent behavior (Hay et al., 2004).

\section{Factors Influencing the Nature and Structure of Friendship Relations in School}

Yet, even though schools offer opportunity structures for the development of friendship relations between different students, numerous research findings indicate that friendships are also structured by students' characteristics and their membership in different social categories, resulting in a preference to choose as friends peers with similar characteristics or similar sociocultural backgrounds (e.g., the literature review by McPherson et al., 2001). This tendency toward homogeneity in social relationships is known as homophily (Lazarsfeld \& Merton, 1954). In the school context, previous research mainly indicates tendencies toward the formation of homogeneous friendships with classmates belonging to the same group as regards grouping attributes such as sex (e.g., Laniado et al., 2016; Neal, 2010) or immigrant background (e.g., Krawinkel et al., 2018; Leszczensky \& Pink, 2015). Thus, the selection of homogeneous friendship relations is not only a cause of group memberships prestructured by social categories, it can also increase already existing disadvantages of minority groups in the classroom, potentially increasing segregation and marginalization. Yet, despite the tendency of students to make friends with same-group peers who are similar to themselves (e.g., regarding ethnic origin), other factors also promote friendship formations between different-group peers such as openness for interethnic friendships (e.g., Hamm et al., 2005; Reinders et al., 2006).

To summarize, previous research shows that peers as well as the kind and quality of peer relations play an important role in students' development in (early) adolescence. These effects might depend on peer-group characteristics, the prevailing norms within the peer group as well as students' individual conditions and dispositions. 


\section{Effects of School and Classroom Composition on Students' Development}

The fact that the composition of the individual social environment might affect the quantity, quality, and nature of a person's social relationships has already been described in various theoretical approaches such as social contact theory (Allport, 1954; Pettigrew, 1998) or social constrict theory (Putnam, 2000). As to the empirical evidence, Hamm et al. (2005), for example, examined the effects of individual- and school-level factors on intergroup friendships. Based on a high-school sample (grades 9-12) from the United States, they found that school composition regarding parental education and academic success orientation can promote or inhibit students' crossethnic friendship nominations and is therefore associated with different nomination patterns between schools. The findings of Demanet et al. (2012) also indicated that ethnic diversity in schools can negatively affect the number of friendships in the sense of the constrict theory, though they determined that these effects can be explained by the socioeconomic student composition of the school. What, to our knowledge, has not yet been addressed by research, however, is whether different indicators characterizing classroom composition might play a role in students' friendships with their classmates. This is quite surprising as there is a rich body of research based on multilevel analysis approaches that show that the social context of learning environments in the classroom and at school can largely influence the individual development of students. Classroom composition effects on academic achievement outcomes were extensively documented in empirical studies (e.g., Hattie, 2002; Luyten et al., 2009; Scharenberg, 2012; Van Ewijk \& Sleegers, 2010). At the same time, more and more recently published studies demonstrated the compositional effects of the student body on non-cognitive outcomes, such as students' motivational or social-emotional development (e.g., Belfi et al., 2012; Hornstra et al., 2015; Rjosk et al., 2015; Scharenberg, 2016). In summary, these studies usually show the advantages of more privileged classrooms. On average, and with regard to a broad variety of developmental aspects, especially academic achievement, students seem to benefit more if their classmates come from families with higher socioeconomic backgrounds or have higher levels of education (Müller \& Zurbriggen, 2016; Van Ewijk \& Sleegers, 2010).

\section{Research Questions}

Despite the evidence of classroom composition effects on learning outcomes, to date there is little evidence of the relevance of the specific classroom pool of peers for establishing friendships. Thus, the question of whether the specific kind of composition of the classroom environment also affects the social relations of students in their classrooms is still unresolved. The present study thus examines whether classroom composition matters for students' friendships, addressing whether social relations in educational settings are affected by contextual factors. This is also of particular theoretical interest as the classroom is an involuntary peer group (Juvonen \& Galván, 2008), meaning that students can usually not choose the classroom they attend or the classmates they meet there. And yet, the classroom and the composition of the peers might influence students' peer relations in the sense that it prestructures contact opportunities between students which might result in more or less mutual friendships.

The present paper addresses this topic by focusing on a student sample in lower-secondary comprehensive schools. First, we examined whether there are systematic differences in the peer relations of students between different classrooms (Research Question 1) and whether classroom composition affects the peer relations of students in these classrooms (Research Question 2).

\section{Sample and Methods}

\section{The Present Study}

Our study was conducted in secondary comprehensive schools (Gemeinschaftsschule) in Baden-Wuerttemberg, a Federal State in southwestern Germany. In the context of the tracked German school system at the secondary level, these comprehensive schools have been established in Baden-Wuerttemberg since 2012 in addition to the stillexisting low-track (Hauptschule or Werkrealschule), intermediate-track (Realschule), and academic-track schools (Gymnasium). The new comprehensive schools feature an inclusive concept: All students, regardless of their individual abilities, learn together in the same classroom, but are taught at three educational levels with different academic requirements. The school provides all schoolleaving certificates in lower-secondary education ${ }^{1}$ (Wacker \& Bohl, 2016). Thus, this kind of comprehensive school

In some comprehensive schools, students can also take their A-levels (Abitur) after the completion of an upper-secondary education. 
explicitly foregoes tracking and addresses a much more diverse and heterogeneous student population - including, among others, students with special educational needs.

\section{Description of the Sample}

A total of $n=821$ students in 52 classes from grades $5(n=$ 262), $6(n=288)$, and $7(n=271)$ from 20 public comprehensive schools participated in our study. Participation was voluntary, and students had to provide written parental consent. For the analyses presented here, we selected those 48 classes $(n=791)$ in which at least 10 students participated. The mean number of students in the classes in this subsample was $M=16.3$ with an average participation rate of $78.0 \%$ per class. The average age of the participating students was $M=12.5$ years $(S D=0.99)$. Most of the students had been born in Germany (85.7\%), and $70.4 \%$ reported having always or almost always spoken German at home. The slightly higher percentage of male students $(54.5 \%)$ in our sample corresponded well to the gender distribution at all secondary comprehensive schools in the Federal State of Baden-Wuerttemberg (55.3\% male; Statistisches Landesamt Baden-Württemberg, 2018). Similarly, the proportion of students with an immigrant background in our sample $(29.6 \%)$ was roughly in line with the proportion as shown for this type of school in the official statistics (31.1\%; ibid.). The proportion of students with special educational needs in our sample was $13.8 \%$ and thus just slightly higher than the respective statewide average for comprehensive schools (12.6\%; Landesinstitut für Schulentwicklung, 2018). Concerning the gender-related and sociocultural composition, our sample can therefore be considered to be approximately representative of the student body composition at secondary public comprehensive schools in the Federal State of Baden-Wuerttemberg.

\section{Instruments}

The study was conducted in the second term of the school year 2017/2018 during regular school hours. Data were collected using a paper-and-pencil questionnaire administered during a lesson of 45 minutes. We measured students' friendship relations using a sociometric ap- proach (Moreno, 1934). In our questionnaire, students were asked to name their friends in the class (Who are your friends in class?; Bukowski et al., 1996). To increase the reliability and validity of this measurement, we did not limit the number of possible peer nominations (Cillessen \& Marks, 2017).

As a measure of students' friendship relations within the classroom, we used the number of reciprocal friendships for each student which were operationalized by mutual nominations of students who nominated each other. Using this conceptualization allowed us to interpret friendships as bilaterally confirmed positive social relationships between two students. With this information, students refer to the experiences they have with particular others in the classroom, indicating, for example, mutual liking and positive affects (Bukowski et al., 1996). To avoid biases due to different class sizes and participation rates within classes, we normalized this sociometric measure, as suggested by Jansen (2006, p. 104):

$$
\text { reciprocal friendships }=\frac{R_{i j}}{n_{j}} \cdot\left(\emptyset n_{a l l}-1\right)
$$

with $\mathrm{R}_{i j}$ being the absolute number of reciprocal nominations of student $i$ in class $j, \mathrm{n}_{j}$ representing the number of participating students in class $j$, and $\varnothing n_{\text {all }}$ the average number of participating students per class. ${ }^{2,3}$ The resulting value indicates the number of reciprocal friendships a student would have within a classroom with an average number of participating students. In the multilevel models, the intercept can therefore be interpreted as the number of friendships of an average student in an average class.

In addition, the student background questionnaire assessed sociodemographic characteristics such as sex $(0$ $=$ female, $1=$ male $)$ and immigrant background, which was operationalized by the language spoken at home $(0=$ (mostly) German, 1 = (partly or mostly) a foreign language; Kelly, 2003). Students' information about their parents' occupation was used as an indicator of their socioeconomic status (SES) and was transformed into the highest International Socio-Economic Index of Occupational Status (HISEI; Ganzeboom et al., 1992). As an indicator of cognitive abilities, we used a 7-min standardized nonverbal reasoning test (KFT 4-12+R; Heller \& Perleth, 2000) with 25 items in multiple-choice format, which

\footnotetext{
We also checked whether the participation rate in a class could have had an effect on the number of reciprocal friendship nominations. However, the correlation between the average number of reciprocal nominations with the average participation rate in classrooms was not significant $(r=.064, p=.665)$.

3 All the students in the classroom could be nominated as friends via the class list in the questionnaire, even those who did not participate. Information on non-participating students, however, was not included in our analyses.
} 
showed a high reliability in our study (Cronbach's alpha = 0.88).

\section{Statistical Analyses}

\section{Analyzing Hierarchical Data}

We chose a multilevel approach for analysis as our research questions related to the relevance of the classroom environment for students' friendships with their peers in the class. The dependent variable at individual level was the reciprocal friendship nominations of students within the classroom, normalized to the different class sizes and participation rates within classes in our sample. At the first level (within-level), multilevel models comprised student-level predictors. At the second level (between-level), regression equations were modeled for different sets of classroom composition characteristics as predictors. Hierarchical linear models were specified using the software $R$ (R Core Team, 2019) applying the packages lme4 (Bates et al., 2015) and mitml (Grund et al., 2019).

We chose a stepwise model specification approach as suggested by Hox et al. (2018): In a first step, we examined the decomposition of variance for the dependent variable. This unconditional model (Model 0) provided information on how much of the variance of the outcome variable was attributable to differences between students (level 1) and between classes (level 2), respectively (Research Question 1). According to Hox et al. (2018), it is justified to account for differences at the aggregate level by multilevel analyses only when at least $10 \%$ of the variance in the dependent variable can be attributed to this level.

In a second step, we simultaneously added sex, immigrant background, socioeconomic status, and cognitive ability as control variables at the individual level (Model 1). In a third step, we specified a set of estimation models with each model comprising only a single classroom-level variable (Research Question 2). As indicators of classroom composition characteristics we added the percentage of boys (Model 2a), the percentage of immigrant students (Model 2b) as well as the classroom-related means of the HISEI (Model 2c) and cognitive ability (Model 2d). Model 3 was fully specified at the aggregate level with all four classroom composition variables.

Regarding the centering of variables, we transformed continuous predictors (HISEI, cognitive ability) at the student level into $z$-scores $(M=0, S D=1)$, which were thus centered to the mean of the whole analysis sample. At the aggregate level, we added predictors as relative proportions (percentage of boys and of students with an immigrant background) or classroom averages of the $z$ scores (average socioeconomic status and cognitive ability), respectively, which were also centered around their grand mean. The resulting coefficients in the multilevel models can thus be interpreted as follows: The intercept indicates the average number of reciprocal friendship nominations for an average student, i.e., a girl speaking (mostly) German at home with an average social background and an average cognitive ability attending a classroom where the number of participating students in our study was average. The unstandardized regression coefficients $(B)$ as predictors at the student level indicate the change in the number of reciprocal friendship nominations when changing from a given category to the reference category in case of dummy variables (e.g., the difference in reciprocal friendship nominations between boys and girls) or when changing a predictor variable by one standard deviation in case of continuous variables (e. g., cognitive ability). At the aggregate level, the regression coefficients indicate how the number of reciprocal friendship nominations changes when the predictors at the classroom level change by one standard deviation.

The goodness of fit of the estimation models was assessed by two different measures: We used the amount of explained variance $\left(R^{2}\right)$ of the dependent variable at the within- and between-level, following the approach by Raudenbush and Bryk (2002). We then conducted model comparisons following the approach for multiply imputed data sets as suggested by Meng and Rubin (1992). All significance tests were performed with $p<.05$.

\section{Handling Missing Data}

For the dependent variable, answers were complete for all students in the analysis sample. The proportions of missing data for individual student characteristics were small (sex: $1.1 \%$, cognitive abilities: $1.3 \%$, immigrant background: $3.8 \%$ ), and somewhat higher for socioeconomic background (HISEI, $15.3 \%$ ). Single missing values regarding students' characteristics were estimated using a joint modeling multilevel multiple imputation approach (Grund et al., 2018; Grund et al., 2019) with $m=20$ imputations. Classroom compositional characteristics were calculated for each imputed data set after imputation. 
Table 1. Number of reciprocal friendship nominations according to student background characteristics

\begin{tabular}{|c|c|c|c|c|}
\hline & $N$ & M & $(S D)$ & Mean difference ${ }^{4}$ \\
\hline \multicolumn{5}{|l|}{ Sex } \\
\hline Girls & 356 & 4.19 & $(2.64)$ & \multirow[t]{2}{*}{$t(780)=1.99 *, p=.047$} \\
\hline Boys & 426 & 3.82 & $(2.58)$ & \\
\hline \multicolumn{5}{|c|}{ Immigrant background ${ }^{1}$} \\
\hline No & 536 & 3.88 & $(2.51)$ & \multirow[t]{2}{*}{$t(382.03)=-1.90^{\dagger}, p=.059$} \\
\hline Yes & 225 & 4.29 & $(2.87)$ & \\
\hline \multicolumn{5}{|c|}{ Socioeconomic status ${ }^{2,3}$} \\
\hline Q1 & 169 & 4.23 & $(2.84)$ & \multirow[t]{4}{*}{$F(3,666)=1.19, p=.313$} \\
\hline Q2 & 168 & 4.19 & $(2.43)$ & \\
\hline Q3 & 166 & 4.15 & $(2.52)$ & \\
\hline Q4 & 167 & 3.77 & $(2.40)$ & \\
\hline \multicolumn{5}{|c|}{ Cognitive ability ${ }^{2}$} \\
\hline Q1 & 206 & 3.69 & $(2.67)$ & \multirow[t]{4}{*}{$F(3,777)=2.30^{\dagger}, p=.076$} \\
\hline Q2 & 202 & 4.07 & $(2.56)$ & \\
\hline Q3 & 186 & 4.38 & $(2.65)$ & \\
\hline Q4 & 187 & 3.96 & $(2.50)$ & \\
\hline$\overline{\text { Total }}$ & 791 & 4.00 & $(2.60)$ & \\
\hline
\end{tabular}

Note. Descriptive statistics based on unimputed data. ${ }^{1}$ Language spoken at home: German. Degrees of freedom (df) adjusted due to heterogeneous variances. ${ }^{2}$ Report of quartiles (Q). Q1: lowest quartile, Q4: highest quartile. ${ }^{3}$ Family's highest socioeconomic status (HISEI). ${ }^{4}$ Mean difference between variable categories. ${ }^{* *} p<.001,{ }^{* \star} p<.01,{ }^{*} p<.05,{ }^{\dagger} p<.10$.

\section{$\underline{\text { Results }}$}

\section{Descriptives at the Student and the Classroom Level}

Table 1 displays the descriptive analyses ${ }^{4}$. The average number of students' reciprocal friendship nominations was $M=4.00(S D=2.60)$. However, it should be noted that students awarded more nominations (outdegree) than they received (indegree): On average, students nominated $7.07(S D=4.42)$ friends in the class and received $5.90(S D$ $=2.84$ ) nominations from their peers. Girls had significantly more reciprocal friendships than boys $(t(780)=$ $1.99, p=.047)$, though this difference was, according to Cohen (1988), a small effect (Cohen's $d=0.14)$. Students with and without immigrant background did not differ significantly in their reciprocal friendship nominations $(t(382.03)=-1.90, p=.059)$. We observed no significant differences between quartiles regarding students' SES $(F(3,666)=1.19, p=.313)$ and cognitive ability $(F(3,777)=$ 2.30, $p=.076)$.

\section{Correlation Analyses}

Table 2 shows the bivariate correlations between the predictors at the individual and the aggregate level with reciprocal friendship nominations as the dependent variable at the student level (left column) and the classroom level (right column). At the student level, the correlation between sex and the number of reciprocal friendship nominations for each student was significant, but negligible $(r=-.071, p=.047)$. Correlations between the number of reciprocal friendship nominations and students' immigrant background, SES, and cognitive ability were not significant. At the classroom level, a higher percentage of students with an immigrant background was positively associated with a higher average number of reciprocal friendship nominations within classrooms $(r=$ $.322, p=.026)$. Conversely, we found that the higher the average SES in the classroom, the lower was the average number of reciprocal friendship nominations $(r=-.400, p$ $=.005)$. The proportion of girls and boys, respectively, as well as the mean cognitive ability in the classes were not significantly correlated with the number of reciprocal friendship nominations.

\footnotetext{
4 The analyses of descriptives and mean differences are based on unimputed data. As a robustness check, we also checked for differences due to imputation and found no significant differences between unimputed and imputed data.
} 
Table 2. Correlation analyses

\begin{tabular}{|c|c|c|c|c|}
\hline & \multicolumn{2}{|c|}{$\begin{array}{l}\text { Student level: } \\
\text { Number of students' reciprocal } \\
\text { friendship nominations }(n=791)\end{array}$} & \multicolumn{2}{|c|}{$\begin{array}{l}\text { Classroom level: } \\
\text { Average number of students' friendship } \\
\text { nominations within classrooms }(n=48)\end{array}$} \\
\hline & $r$ & $p$ & $r$ & $p$ \\
\hline Sex & $-.071 *$ & .047 & $-.267^{\dagger}$ & .066 \\
\hline Immigrant background ${ }^{2}$ & $.070^{+}$ & .056 & $.322^{*}$ & .026 \\
\hline Socioeconomic status & .039 & .274 & $-.400 * \star$ & .005 \\
\hline Cognitive ability & -.063 & .106 & -.125 & .398 \\
\hline
\end{tabular}

Note. Correlations according to Pearson (Pearson's r). Predictors at the student level relate to the background characteristics of individual students. Predictors at the classroom level relate to classroom composition characteristics (percentage of male students and with an immigrant background; averages of socioeconomic status and cognitive ability). ${ }^{1} 0=$ female, $1=$ male. ${ }^{2}$ Language spoken at home: German. ${ }^{\star * \star} p<.001,{ }^{*} p<.01,{ }^{\star} p<.05,{ }^{\dagger} p<.10$.

\section{Classroom-Level Differences in the Reciprocal Friendship Nominations of Students}

Concerning Research Question 1, we analyzed the variance of the number of reciprocal friendship nominations at the student level in an otherwise "empty" estimation model without any further predictors. This resulted in a significant intraclass correlation (ICC). The variance decomposition yielded a significant ICC of .226 $(p<$ .001), i.e., almost $23 \%$ of the differences in students' average number of reciprocal friendship nominations were attributable to differences between classrooms. This value was well beyond the threshold of an ICC $>.10$ (Hox et al., 2018) typically required to account for the nested data structure.

\section{Predicting Reciprocal Friendship Nominations by Student Background Characteristics}

We first predicted students' reciprocal friendship nominations by their individual background characteristics before including predictors at the classroom level. At the individual level (Table 3, Model 1), neither sex, immigrant background, SES, nor cognitive ability were significantly related to students' reciprocal friendship nominations. Consequently, the student-level variables considered did not explain a significant amount of the within-classroom variance of students' reciprocal friendship nominations or of the variance at the aggregate level $\left(R_{\mathrm{L} 1}^{2}=.003, R_{\mathrm{L} 2}^{2}=\right.$ .018). Accordingly, predicting reciprocal friendship nominations by the individual background characteristics of students did not lead to a significant improvement of this model compared to the unconditional model $(F(4,12949)$ $=1.59, p=.174)$.

\section{Classroom Composition Effects on the Reciprocal Friendship Nominations of Students}

Regarding Research Question 2, the classroom composition indicators were added in four separate estimation models, each containing the variables at the individual level and one of the single level-2 predictors. At the classroom level, gender distribution (Model 2a) and average cognitive ability level (Model 2d) had no significant effect on students' reciprocal friendship nominations and therefore did not contribute to an improvement of the model fit compared to Model 1. For the percentage of students with an immigrant background (Model 2b) as well as for the average SES at the classroom level (Model 2c), we observed significant effects on the outcome variable: Students' reciprocal friendship nominations were higher in classrooms with an above-average percentage of students with an immigrant background $(B=$ $0.42, p=.035)$ and lower in socioeconomically more privileged classrooms $(B=-1.34, p=.003)$. Both models showed a significantly improved goodness of fit compared to Model 1 (Model 2b vs. Model 1: $p=.036$; Model 2c vs. Model 1: $p=.005)$.

In the next step, we fully specified the estimation model, comprising all variables at the student and the classroom level. Model 3 showed at the aggregate level that classrooms with a higher average SES were negatively associated with the number of students' reciprocal friendship nominations in the classroom $(B=-1.21, p=$ .017). All other predictor variables in the fully specified model were not significant. This was also true for the percentage of students with an immigrant background that had shown a significant effect when considered as a single level-2 predictor (Model 2b). Obviously, this effect became insignificant when controlling for the average SES in the fully specified model. Adding all classroom composition characteristics into the estimation model increased the amount of explained variance at the aggregate level 


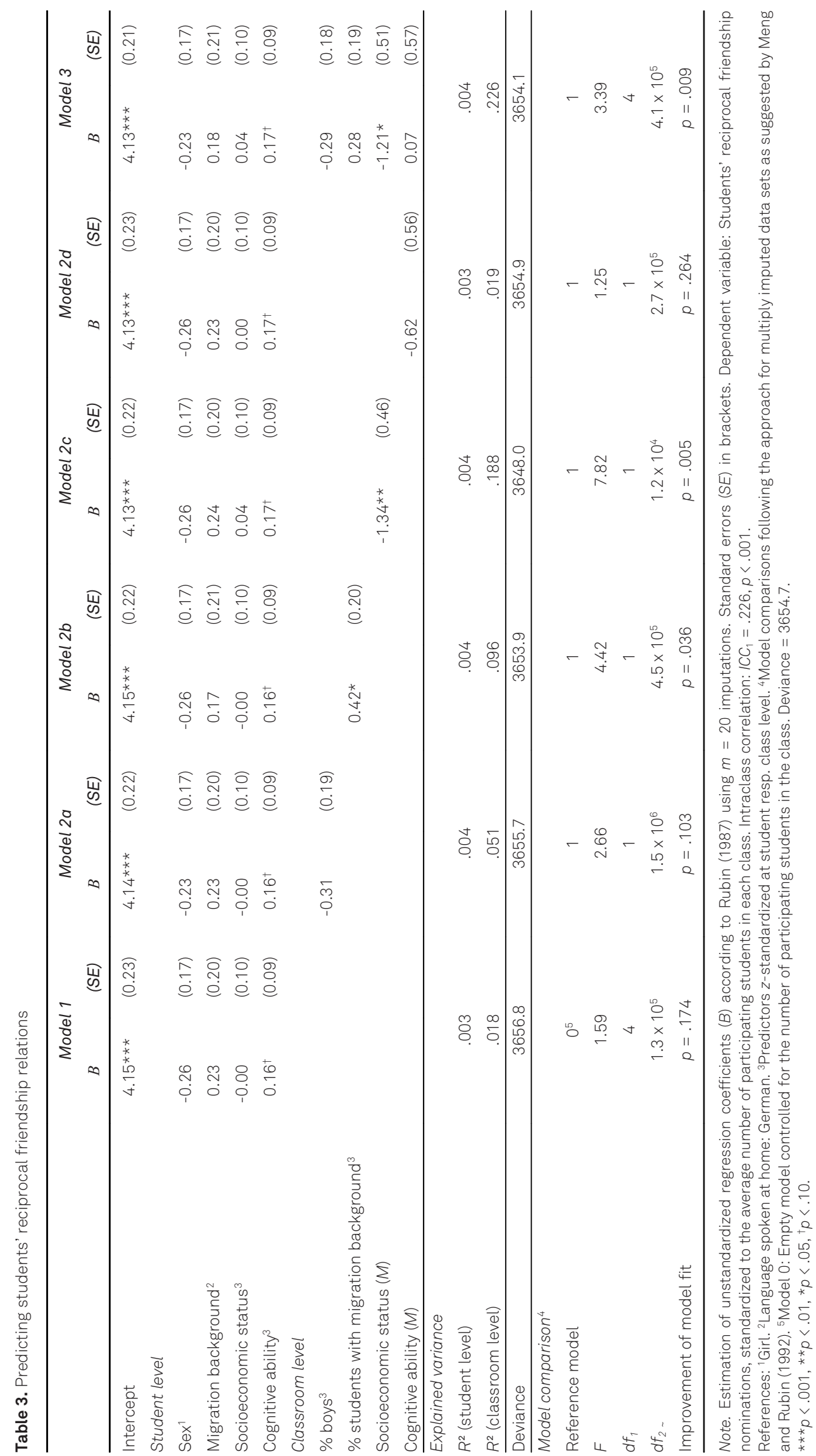




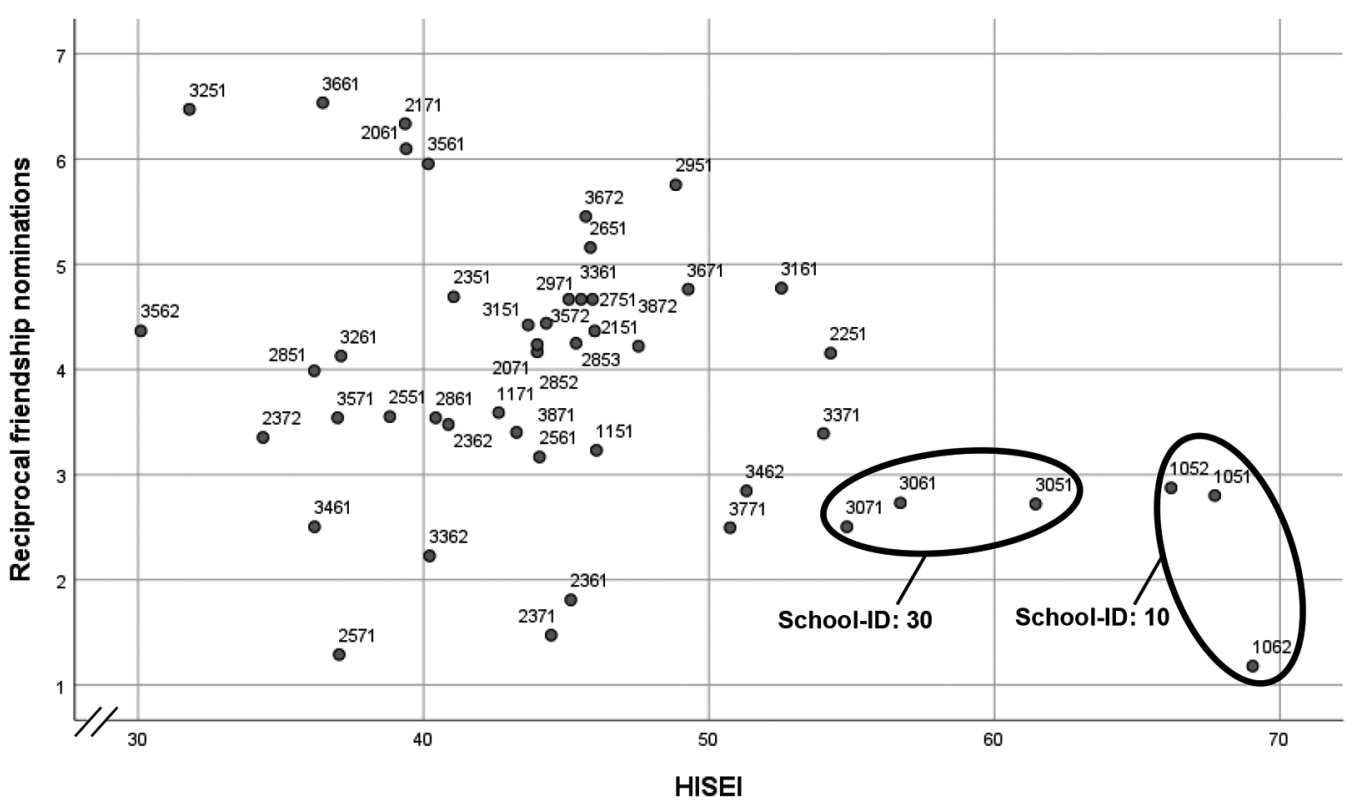

Note. Point labeling: two-digit school-ID followed by two-digit class-ID.

Figure 1. Classroom averages of socioeconomic status (HISEI) and reciprocal friendship nominations.

compared to Model 1 by about 20 percentage points $\left(R^{2}=\right.$ $.226)$ and significantly improved the goodness of fit $(F(4$, $41147)=3.39, p=.009$ ).

To further investigate the negative effect found for mean socioeconomic status at the classroom level on the number of students' reciprocal friendship nominations, we analyzed the bivariate distribution of these aggregate variables at the classroom level. As Figure 1 shows, the classes in two schools (school-IDs 10 and 30) could be identified as influential observations for this effect. Interestingly, these two schools differed from the other schools in our sample by being known across the region for providing innovative pedagogical concepts.

\section{Discussion}

The present study examined whether differences in students' friendships within classes in secondary school can be explained by differences in classroom composition. A first important result was that classrooms indeed differed significantly in the interrelatedness of their students (Research Question 1): More than one-fifth of the variance in students' reciprocal friendship nominations could be attributed to the classroom level. This indicates that the average number of reciprocal friendship nominations of students is a sensible measure for revealing systematic differences regarding the social context within educational settings. Obviously, classrooms matter for establishing friendships and thereby play an important role in the social integration of students in classes.

Interestingly, at the individual level, the student characteristics considered did not explain a significant amount of the variance in reciprocal friendship nominations $\left(R^{2}=\right.$ .003). Student characteristics like sex, immigrant background, socioeconomic status, and cognitive ability did not seem to play a noteworthy role for having friends in the class. Concerning the quite typical problems of exclusion in school affecting some students more than others (e.g., Plenty \& Jonsson, 2017; Raabe, 2019), the results can be interpreted as a positive acknowledgment of the social culture within the examined comprehensive schools in our study and their inclusive concept of learning.

At the same time, multilevel analyses detected the effects of classroom composition on the number of reciprocal friendship nominations (Research Question 2). Thus, classroom composition characteristics indeed resulted in a certain degree of social advantage or disadvantage for the students. More than $20 \%$ of the variance in students' reciprocal friendship nominations between classes could be explained by classroom composition characteristics. A higher average socioeconomic classroom composition was associated with a lower degree of reciprocal friendship relations between the students in a class. A further in-depth inspection of the classroom-level data revealed that this effect originated primarily from six 
classes of two schools that were known for offering an innovative pedagogical concept and thereby seem to attract more students from socioeconomically privileged families. Such conceptual peculiarities might therefore result in a composition of students who might be less open to establishing and maintaining friendships. Or such schools may simply attract students from a larger catchment area who do not live in the same neighborhood, thus limiting opportunities for establishing friendship relations (e.g., Kruse et al., 2016).

In light of existing research findings showing classroom composition effects on the academic success of students, one could have expected a socioeconomically advantaged student composition to be associated with more positive social peer relations in classes. Interestingly, in our study, the opposite was the case. At the same time, our analyses showed that the reported effect was confounded with a positive effect of the proportion of students with an immigrant background on the number of reciprocal friendship nominations. So, the findings might also be related to a sociocultural momentum.

\section{Limitations}

It should be recalled that the schools in our sample were comprehensive schools with an inclusive pedagogical concept and were therefore more heterogeneous regarding the sociocultural backgrounds and individual learning needs of students than most other secondary school tracks in Germany. The context of inclusive classes as well as the higher heterogeneity of the student body might have impacted the reported results. Future studies should therefore also consider other school tracks with a more homogeneous student sample. $22 \%$ of the students of our analysis sample did not take part in the study (e.g., for reasons of absence due to illness or missing consent of parents). The reported robustness checks of our data did not give any indications of biases, but such effects cannot be completely ruled out. We did not consider information on teacher behavior that might contribute to the development of friendship networks. Furthermore, with the number of mutual friendship nominations between peers in the classroom, we addressed only the quantitative dimension. How student composition in classes might be related to the quality and closeness of the friendships between classmates was not examined in our analyses and would be an interesting topic for further empirical research.

\section{Conclusion}

In the present study, we empirically demonstrated that differences in classroom composition were linked to the degree of positive peer relations in classrooms. Therefore, the composition of the student body evokes differential developmental environments (Baumert et al., 2006) - not only as was already shown for academic, motivational, and emotional outcomes (Hornstra et al., 2015; Müller \& Zurbriggen, 2016; Rjosk et al., 2015), but also regarding opportunities for social interaction and, in consequence, for social learning. This finding expands the current state of classroom composition research. On the one hand, our results surprisingly showed that friendship networks can be systematically less interconnected in socioeconomically more privileged classrooms. Typically, the social relatedness between classmates is considered an important aspect of students' learning environment (GillenO'Neel \& Fuligni, 2013; Looser, 2009; Vanwynsberghe et al., 2017). In this sense, a higher degree of reciprocal friendships may be considered a positive, potentially compensating factor for students' development in otherwise more disadvantaged classrooms. On the other hand, this finding implies that teachers should be aware that a lower amount of friendship relations might occur in socioeconomically more advantaged classrooms, and that pedagogical measures might be needed to strengthen peer relations under such conditions. Measures might include pedagogically working with individual students who are being excluded or with students who exclude others as well as strengthening the overall social cohesion within the classroom by providing opportunities for positive and joyful social interactions between students.

\section{References}

Allport, G. W. (1954). The nature of prejudice. Addison-Wesley.

Bates, D., Maechler, M., Bolker, B., \& Walker, S. (2015). Fitting linear mixed-effects models using Ime4. Journal of Statistical Software, 67(1), 1 - 48. https://doi.org/10.18637/jss.v067.i01

Baumeister, R. F., \& Leary, M. R. (1995). The need to belong: Desire for interpersonal attachments as a fundamental human motivation. Psychological Bulletin, 117(3), 497 - 529. https://doi.org/ 10.1037/0033-2909.117.3.497

Baumeister, R. F., Twenge, J. M., \& Nuss, C. K. (2002). Effects of social exclusion on cognitive processes: Anticipated aloneness reduces intelligent thought. Journal of Personality and Social Psychology, 83(4), 817-827. https://doi.org/10.1037/00223514.83.4.817

Baumert, J., Stanat, P., \& Watermann, R. (2006). Schulstruktur und die Entstehung differenzieller Lern- und Entwicklungsmilieus [School structure and the emergence of differential environments for learning and development]. In J. Baumert, P. Stanat, 
\& R. Watermann (Eds.), Herkunftsbedingte Disparitäten im Bildungswesen: Differenzielle Bildungsprozesse und Probleme der Verteilungsgerechtigkeit. Vertiefende Analysen im Rahmen von PISA 2000 (pp. 95 -188). VS Verlag für Sozialwissenschaften.

Belfi, B., Goos, M., De Fraine, B., \& van Damme, J. (2012). The effect of class composition by gender and ability on secondary school students' school well-being and academic self-concept: A literature review. Educational Research Review, 7(1), 62-74. https://doi.org/10.1016/j.edurev.2011.09.002

Bukowski, W. M., Pizzamiglio, M. T., Newcomb, A. F., \& Hoza, B. (1996). Popularity as an affordance for friendship: The link between group and dyadic experience. Social Development, 5(2), 189 - 202. https://doi.org/10.1111/j.1467-9507.1996.tb00 080.x

Cillessen, A. H. N., \& Marks, P. E. L. (2017). Methodological choices in peer nomination research. New Directions for Child and Adolescent Development, 157(3), 21-44. https://doi.org/10. 1002/cad.20206

Cillessen, A. H. N., \& van den Berg, Y. H. M. (2012). Popularity and school adjustment. In A. M. Ryan \& G. W. Ladd (Eds.), Peer relationships and adjustment at school (pp. 135-165). IAP Information Age Publishers.

Cohen, J. (1988). Statistical power analysis for the behavioral sciences (2nd ed.). Erlbaum.

Deci, E. L., \& Ryan, R. M. (1985). Intrinsic motivation and selfdetermination in human behavior. Plenum.

Deci, E. L., \& Ryan, R. M. (2008). Self-determination theory: A macrotheory of human motivation, development, and health. Canadian Psychology, 49(3), 182 - 185. https://doi.org/10.1037/ a0012801

Demanet, J., Agirdag, O., \& van Houtte, M. (2012). Constrict in the school context: The impact of ethnic school diversity on the quantity and quality of friendships. The Sociological Quarterly, 53(4), 654-675. https://doi.org/10.1111/j.1533-8525.2012. 01245.x

Dishion, T. J., Patterson, G. R., Stoolmiller, M., \& Skinner, M. L. (1991). Family, school, and behavioral antecedents to early adolescent involvement with antisocial peers. Developmental Psychology, 27(1), 172-180. https://doi.org/10.1037/00121649. 27.1.172

Duffy, A. L., \& Nesdale, D. (2009). Peer groups, social identity, and children's bullying behaviour. Social Development, 18(1), 121 139. https://doi.org/10.1111/j.1467-9507.2008.00484.x

Festinger, L., Back, K. W., \& Schachter, S. (1950). Social pressures in informal groups. A study of human factors in housing. Stanford University Press.

Ganzeboom, H. B. G., De Graff, P. M., \& Treiman, D. J. (1992). A standard international socio-economic index of occupational status. Social Science Research, 21(1), 1-56.

Geven, S., Weesie, J., \& van Tubergen, F. (2013). The influence of friends on adolescents' behavior problems at school: The role of ego, alter and dyadic characteristics. Social Networks, 35(4), 583 - 592. https://doi.org/10.1016/j.socnet.2013.08.002

Gillen-O'Neel, C., \& Fuligni, A. (2013). A longitudinal study of school belonging and academic motivation across high school. Child Development, 84(2), 678-692. https://doi.org/10.1111/j.14678624.2012.01862.x

Grund, S., Lüdtke, O., \& Robitzsch, A. (2018). Multiple imputation of missing data for multilevel models: Simulations and recommendations. Organizational Research Methods, 2(1), 111-149. https://doi.org/10.1177/1094428117703686

Grund, S., Robitzsch, A., \& Luedtke, O. (2019). mitml: Tools for multiple imputation in multilevel modeling. $R$ package version $0.3-7$. Retrieved from https://CRAN.R-project.org/package= mitml
Hamm, J. V., Brown, B. B., \& Heck, D. J. (2005). Bridging the ethnic divide: Student and school characteristics in African American, Asian-descent, Latino, and White adolescents' cross-ethnic friend nominations. Journal of Research on Adolescence, 15(1), 21 - 46. https://doi.org/10.1111/j.1532-7795.2005.00085.x

Hanish, L. D., \& Guerra, N. G. (2002). A longitudinal analysis of patterns of adjustment following peer victimization. Development and Psychopathology, 14(1), 69-89. https://doi.org/10. 1017/S0954579402001049

Hannover, B., Kreutzmann, M., Haase, J., \& Zander, L. (2020). Growing together: Effects of a school-based intervention promoting positive self-beliefs and social integration in recently immigrated children. International Journal of Psychology, 55(5), 713 - 722. https://doi.org/10.1002/ijop.12653

Hattie, J. A. C. (2002). Classroom composition and peer effects. International Journal of Educational Research, 37(5), 449-481. https://doi.org/10.1016/S0883-0355(03)00015-6

Hay, D. F., Payne, A., \& Chadwick, A. (2004). Peer relations in childhood. Journal of Child Psychology and Psychiatry, and Allied Disciplines, 45(1), 84-108. https://doi.org/10.1046/j. 0021-9630.2003.00308.x

Heller, K. A., \& Perleth, C. (2000). KFT 4-12+R. Kognitiver Fähigkeitstest für 4. bis 12. Klassen, Revision [KFT 4-12+R. Cognitive abilities test for grades 4-12, revision]. Beltz.

Hornstra, L., van der Veen, I., Peetsma, T., \& Volman, M. (2015). Does classroom composition make a difference: effects on developments in motivation, sense of classroom belonging, and achievement in upper primary school. School Effectiveness and School Improvement, 26(2), 125 -152. https://doi.org/10.1080/ 09243453.2014 .887024

Hox, J. J., Moerbeek, M., \& van de Schoot, R. (2018). Multilevel analysis: Techniques and applications (3rd ed.). Routledge.

Jansen, D. (2006). Einführung in die Netzwerkanalyse. Grundlagen, Methoden, Forschungsbeispiele [Introduction to network analysis. Foundations, methods, research examples]. VS Verlag für Sozialwissenschaften.

Jones, S. E., Bombieri, L., Livingstone, A. G., \& Manstead, A. S. R. (2012). The influence of norms and social identities on children's responses to bullying. British Journal of Educational Psychology, 82(2), 241-256. https://doi.org/10.1111/j.20448279.2011.02023.x

Juvonen, J., \& Galván, A. (2008). Peer influence in involuntary social groups. Lessons from research on bullying. In M. J. Prinstein \& K. A. Dodge (Eds.), Understanding peer influence in children and adolescents (pp. 225 - 244). Guildford.

Kelly, D. L. (2003). Developing the PIRLS background questionnaires. In M. O. Martin, I. V. S. Mullis, \& A. M. Kennedy (Eds.), PIRLS 2001 technical report (pp. 29 - 40). Boston College.

Krawinkel, S., Südkamp, A., Lange, S., Wolf, S. M., \& Tröster, H. (2018). Soziale Akzeptanz und Eigengruppenbevorzugung deutschsprachiger und türkischsprachiger Schülerinnen und Schüler [Social acceptance and in-group bias among German speaking and Turkish speaking students]. Psychologie in Erziehung und Unterricht, 65, 110-124.

Kruse, H., Smith, S., van Tubergen, F., \& Maas, I. (2016). From neighbors to school friends? How adolescents' place of residence relates to same-ethnic school friendships. Social Networks, 44, 130 -142. https://doi.org/10.1016/j.socnet.2015.07. 004

Kulawiak, P. R., \& Wilbert, J. (2015). Methoden zur Analyse der sozialen Integration von Schulkindern mit sonderpädagogischem Förderbedarf im gemeinsamen Unterricht [Methods for analyzing the social integration of children with special educational needs in mainstream education]. Empirische Sonderpädagogik, 7(3), $241-257$. 
Landesinstitut für Schulentwicklung. (2018). Bildungsberichterstattung 2018. Bildung in Baden-Württemberg. Author.

Laniado, D., Volkovich, Y., Kappler, K., \& Kaltenbrunner, A. (2016). Gender homophily in online dyadic and triadic relationships. EPJ Data Science, 5(19), 1 - 23.

Lazarsfeld, P. F., \& Merton, R. K. (1954). Friendship as social pcrocess: A substantive and methodological analysis. In $\mathrm{M}$. Berger, T. Abel, \& C. H. Page (Eds.), Freedom and control in modern society (pp. 18-66). Van Nordstrand.

Leszczensky, L., \& Pink, S. (2015). Ethnic segregation of friendship networks in school: Testing a rational-choice argument of differences in ethnic homophily between classroom- and grade-level networks. Social Networks, 42, 18- 26.

Looser, D. (2009). Soziale Beziehungen und Leistungsmotivation. Die Bedeutung von Bezugspersonen für die längerfristige Aufrechterhaltung der Lern- und Leistungsmotivation [Social relationships and achievement motivation. The importance of attachment figures for the longer-term maintenance of learning and achievement motivation]. Budrich UniPress.

Luyten, H., Schildkamp, K., \& Folmer, E. (2009). Cognitive development in Dutch primary education, the impact of individual background and classroom composition. Educational Research and Evaluation, 15(3), 265-283. https://doi.org/10.1080/ 13803610902955333

Lyubomirsky, S., Sheldon, K. M., \& Schkade, D. (2005). Pursuing happiness: The architecture of sustainable change. Review of General Psychology, 9(2), 111-131. https://doi.org/10.1037/ 1089-2680.9.2.111

McCormick, M. P., Cappella, E., Hughes, D. L., \& Gallagher, E. K. (2015). Feasible, rigorous, and relevant: Validation of a measure of friendship homophily for diverse classrooms. The Journal of Early Adolescence, 35(5-6), 817-851.

McPherson, M., Smith-Lovin, L., \& Cook, J. M. (2001). Birds of a feather: Homophily in social networks. Annual Review of Sociology, 27, 415-444. https://doi.org/10.1146/annurev.soc. 27.1.415

Meng, X. L., \& Rubin, D. B. (1992). Performing likelihood ratio tests with multiply-imputed data sets. Biometrika, 79(1), 103-111. https://doi.org/10.1093/biomet/79.1.103

Moreno, J. L. (1934). Who shall survive? A new approach to the problem of human interrelations. (Nervous and Mental Disease Monograph Series, No. 58). Nervous and Mental Disease Publishing Co.

Müller, C. M., Hofmann, V., \& Arm, S. (2017). Susceptibility to classmates' influence on delinquency during early adolescence. Journal of Early Adolescence, 37(9), 1221-1253. https://doi. org/10.1177/0272431616653475

Müller, C. M., \& Zurbriggen, C. L. A. (2016). An overview of classroom composition research on social-emotional outcomes: Introduction to the Special Issue. Journal of Cognitive Education and Psychology, 15(2), 163 -184. https://doi.org/10. 1891/1945-8959.15.2.163

Neal, J. W. (2010). Hanging out: Features of urban children's peer social networks. Journal of Social and Personal Relationships, 27(7), $982-1000$.

Pettigrew, T. F. (1998). Intergroup contact theory. Annual Review of Psychology, 49, 65-85. https://doi.org/10.1146/annurev. psych.49.1.65

Pittman, L. D., \& Richmond, A. (2007). Academic and psychological functioning in late adolescence: The importance of school belonging. The Journal of Experimental Education, 75(4), $270-$ 290.

Plenty, S., \& Jonsson, J. O. (2017). Social exclusion among peers: The role of immigrant status and classroom immigrant density. Journal of Youth and Adolescence, 46, 1275-1288. https://doi. org/10.1007/s10964-016-0564-5
Putnam, R. D. (2000). Bowling alone: The collapse and revival of American community. Simon \& Schuster.

Raabe, I. J. (2019). Social exclusion and school achievement: Children of immigrants and children of natives in three European countries. Child Indicators Research, 12, 1003-1022. https://doi.org/10.1007/s12187-018-9565-0

R Core Team. (2019). R: A language and environment for statistical computing. R Foundation for Statistical Computing. Retrieved from https://www.R-project.org/

Raudenbush, S. W., \& Bryk, A. S. (2002). Hierarchical linear models. Applications and data analysis methods (2nd ed., Vol. 1). Sage.

Reinders, H., Greb, K., \& Grimm, C. (2006). Entstehung, Gestalt und Auswirkungen interethnischer Freundschaften im Jugendalter. Eine Längsschnittstudie [Formation, shape and effects of interethnic friendships in adolescence. A longitudinal study]. Diskurs Kindheits- und Jugendforschung, 1(1), $39-57$.

Rjosk, C., Richter, D., Hochweber, J., Lüdtke, O., \& Stanat, P. (2015). Classroom composition and language minority students' motivation in language lessons. Journal of Educational Psychology, 107(4), 1171-1185. https://doi.org/10.1037/edu0000035

Rubin, D. B. (1987). Multiple imputation for nonresponse in surveys. Wiley.

Scharenberg, K. (2012). Leistungsheterogenität und Kompetenzentwicklung. Zur Relevanz klassenbezogener Kompositionsmerkmale im Rahmen der KESS-Studie [Achievement heterogeneity and competence development. The relevance of classroom composition characteristics in the context of the KESS study]. Waxmann.

Scharenberg, K. (2016). The interplay of social and ethnic classroom composition, tracking and gender on students' school satisfaction. Journal of Cognitive Education and Psychology, 15(2), 320 - 346. https://doi.org/10.1891/1945-8959.15.2.320

Schwab, S. (2016). Erfassung von sozialer Partizipation - Übereinstimmung zwischen Selbst- und Fremdsicht von Schülern mit und ohne sonderpädagogischen Förderbedarf [Assessment of social participation - Agreement between self- and other perceptions of social participation of students with and without special educational needs]. Zeitschrift für Pädagogische Psychologie, 30(4), 227 -236. https://doi.org/10.1024/1010-0652/ a000187

Statistisches Landesamt Baden-Württemberg. (2018). Allgemeinbildende Schulen in Baden-Württemberg im Schuljahr 2017/18 [General education schools in Baden-Württemberg in the 2017/ 18 school year]. Retrieved from www.statistik-bw.de/Service/ Veroeff/Statistische_Berichte/323117001.pdf

Van Ewijk, R., \& Sleegers, P. (2010). The effect of peer socioeconomic status on student achievement. A meta-analysis. Educational Research Review, 5(2), 134-150. https://doi.org/ 10.1016/j.edurev.2010.02.001

Vanwynsberghe, G., Vanlaar, G., Van Damme, J., \& De Fraine, B. (2017). Long-term effects of primary schools on non-cognitive outcomes of students at age 17. Studies in Educational Evaluation, 55, 83 - 93. https://doi.org/10.1016/j.stueduc.2017.07.005

Wacker, A., \& Bohl, T. (2016). Schulsystem und Gemeinschaftsschule in Baden-Württemberg [School system and comprehensive school in Baden-Wuerttemberg]. In T. Bohl \& A. Wacker (Eds.), Die Einführung der Gemeinschaftsschule in BadenWürttemberg. Abschlussbericht der wissenschaftlichen Begleitforschung (WissGem) (pp. 27 - 44). Waxmann.

Walton, G. M., \& Cohen, G. L. (2011). A brief social-belonging intervention improves academic and health outcomes of minority students. Science, 331(6023), 1447-1451. https://doi.org/ 10.1126/science.1198364

Zander, L., \& Kreutzmann, M. (2018). Ich, Wir und die Anderen: Die Bedeutung der Peergruppe für schulische Entwicklungsverläufe in heterogenen Bildungskontexten [Me, us, and them: The 
importance of peer groups for developmental trajectories in heterogeneous educational school contexts]. In N. McElvany, W. Bos, H. G. Holtappels, J. Hasselhorn, \& A. Ohle-Peters (Eds.), Bedingungen erfolgreicher Bildungsverläufe in gesellschaftlicher Heterogenität. Interdisziplinäre Forschungsbefunde und Perspektiven für Theorie und Praxis (pp. $103-118$ ). Waxmann.

\section{Funding}

We are indebted to the Baden-Württemberg Stiftung for the financial support of this research project by the Eliteprogramme for Postdocs. The professorship of Katja Scharenberg is sponsored by the German Federal Ministry of Education and Research (grant no. 01JA1818B).

Open access publication enabled by University of Education Freiburg.

\section{ORCID}

Katja Scharenberg

(iD) https://orcid.org/0000-0002-6182-2601

Sebastian Röhl

(iD) https://orcid.org/0000-0003-2573-541X

Wolfram Rollett

(iD) https://orcid.org/0000-0002-2357-5160

\section{Prof. Dr. Katja Scharenberg}

Institut für Soziologie

Pädagogische Hochschule Freiburg

Kunzenweg 21

79117 Freiburg

Germany

katja.scharenberg@ph-freiburg.de 